\title{
Impact of the stabilization of compacted cohesive soil - sandy clay on yield criterion improvement
}

\author{
WOJCIECH SAS ${ }^{1}$, ANDRZEJ GŁUCHOWSKI ${ }^{2}$, ALOJZY SZYMAŃSKI $^{2}$ \\ Water Center Laboratory ${ }^{1}$, Department of Geotechnical Engineering ${ }^{2}$ \\ Warsaw University of Life Sciences - SGGW
}

\begin{abstract}
Impact of the stabilization of compacted cohesive soil - sandy clay on yield criterion improvement. Soft soils, exhibiting low strength properties in the case of external load, require improvement. Chemical stabilization is easy in preparing and presents very good results in improving mechanical properties. In this paper, results of CBR and unconfined compressive strength test are presented for cohesive soil - sandy clay. Stabilization medium was Reymix, which is a cement derivative. Conducted tests define the characteristics of mechanical properties improvement and estimate yield criterion for stabilized soil during the time of stabilization, which is different for non-stabilized soils.
\end{abstract}

Key words: stabilization, Reymix, yield criterion, cohesive soil, unconfined compressive test, CBR

\section{INTRODUCTION}

Yielding of soils in term of one-dimensional loading can be defined as a stress value leading to plastic deformation. This phenomenon can be represented graphically by a point. For two and three dimensional yield, stress will be represent by a curve and a surface respectively. This consideration of stress configuration led to establishing yield surface placed in stress space. Respectively to upper statements, when stress state is placed in yield surface, no plastic deformation will occur (Yu 2006).

Phenomenon of yielding in continuum mechanics, for example of steel or other ductile materials, is described as related to molecular mobility (Royalance 2001). Although yield criterion is well established, the exact point of its occurring is very often unclear.

The reason behind the studies on limit of elasticity is very simple. Better understanding of material yielding can prevent the appearance of plastic strains. Even if avoidance of yield is impossible, predicting when yielding will occur is very important. It should be remembered that the conditions, under which the yielding of soils occurs, are independent from loading stress paths (Lekha et al. 2013).

Yielding is also very closely connected with uncial material properties. For example, in cohesive soils yielding is highly related to water content. Very high water content clay, with moisture crossing liquid limit, has very low yield stress (Fakher et al. 1990).

In order to fulfill land reclamation requirements, an established technique is to find materials and solutions for conventional ground improvement techniques 
during the primary construction stage (Yano et al. 1985).

Soft soil, such as clay or sandy clay, can easily be improved with non-aggressive for environment chemical stabilization. In this case, stabilization with Reymix medium is proposed as a good remedy for poor strength characteristic of cohesive soil. Stabilization with ordinary cement or cement with improved strength characteristic (Reymix) causes a rapid increase of mechanical properties, including bearing capacity, but also alters yield mechanism due to the brittle nature of stabilized soil, when compared with ductile non-stabilized cohesive material (Zabielska-Adamska 2008).

\section{LITERATURE REVIEW}

Nature of yielding can be disturbing as a result of properties of soils. Yielding causes also elastic and plastic strain increments. This fact places the phenomenon of yielding between the initial pure elasticity and post-failure pure plasticity (Puzrin 2012).

Stabilization of soils can immediately change mechanical and physical properties of the material. After 28-day-stabilization, mechanical properties can be up to seven times higher than in the case of non-stabilized soil (Sas et al. 2013). The rising up of strength properties does not coincide with baseline (natural soil). Brittle character of stabilized soil influences strength and this material behaves more like soft rock than hard soil. It improves tensile strength properties (Sas and Głuchowski 2013). Change in mineral structure of cohesive soils also has an influence on yield stress. Chemically-stabilized soils are also suitable to be used as cut-off walls in geo- technical engineering with the assistance of geotechnical soundings (Skutnik and Bajda 2008). Over decades, many studies have been conducted in purpose to describe the properties of stabilized soils. It is worth to note the lack of full understanding physic-chemical mechanism and impact of this relationship from micro to macro scale (Lemaire et al. 2013). The mechanical improvement occurs first by modification in soil texture and in a large part by the development of C-(A)-S-H gel which spans broad zones and creates coverage (Lemaire et al. 2013).

Common way to obtain such parameter as yield stress is a triaxial test. However, this type of equipment is rarely available in pavement testing laboratories. Therefore in order to study the appearance of yielding due to monotonic loading, CBR tests have been performed. This method was extended in next stage by unloading after CBR test procedure was performed. Choice of this method is justified by its popularity in pavement laboratory testing and possible future application in pavement design.

Simple method as CBR test should refer to another uncomplicated way of testing. Therefore, studies on yielding of metal bars in tensile strength test were also taken into consideration. Both tensile strength test and CBR test are onedimensional tests. Difference between them concerns the loading surface. While in tensile strength test all the section is loaded, in CBR test only the area under the piston is subjected to loading. Nevertheless, the aim of the CBR test is to simulate pavement load by using steel ring placed on soil sample. It exerts model stress distribution over tested sample (Vidal and Infante 2014). 


\section{MATERIAL AND METHODS}

One-dimensional (uniaxial) test leads to the deformation of soil sample till yield stress point and after, generally in the case of stabilized specimen hardening. Hardening means that after reaching the yield point, plastic deformation will occur only with the further increase of stress. In case of hold stress in point being greater than yield stress, plastic displacement increment will not multiply.

This theory of elasto-plastic material is used in the Von Mises yield criterion. The Von Mises yield criterion is represented by equation (1):

$f=\sigma_{e}-\sigma_{y}=\left(\frac{1.5 \sigma^{\prime}}{\sigma^{\prime}}\right)^{0.5}-\sigma_{y}$

where:

$f-$ the yield function,

$\sigma_{e}-$ the Von Mises stress,

$\sigma_{y}-$ the initial yield stress,

$\sigma^{\prime}-$ the deviator tensor.

Definition of linear strain hardening function is presented by equation (2): $\varepsilon^{p}=\frac{\sigma-\sigma_{y}}{h_{c}}$

where:

$\varepsilon^{p}$ - the plastic strain,

$h_{c}-$ the hardening constant.

Uniaxial stress conditions after initial yielding are described in stress-strain function by a following equation (3):

$\frac{\mathrm{d} \sigma}{\mathrm{d} \varepsilon}=E_{L}\left(1-\frac{E_{L}}{E_{L}+h_{c}}\right)$

where:

$E_{L}-$ a secant modulus of elastic part of stress-strain relationship.

This dependence is presented by Figure 1.

Forecasting of linear hardening, as is present on Figure 1, depends on the familiarity with the elastic Young modulus $\left(E_{L}\right)$, which is a secant modulus of stress strain curve until point of yielding. Therefore, an easy method of estimating yield point on the basis uniaxial tests is

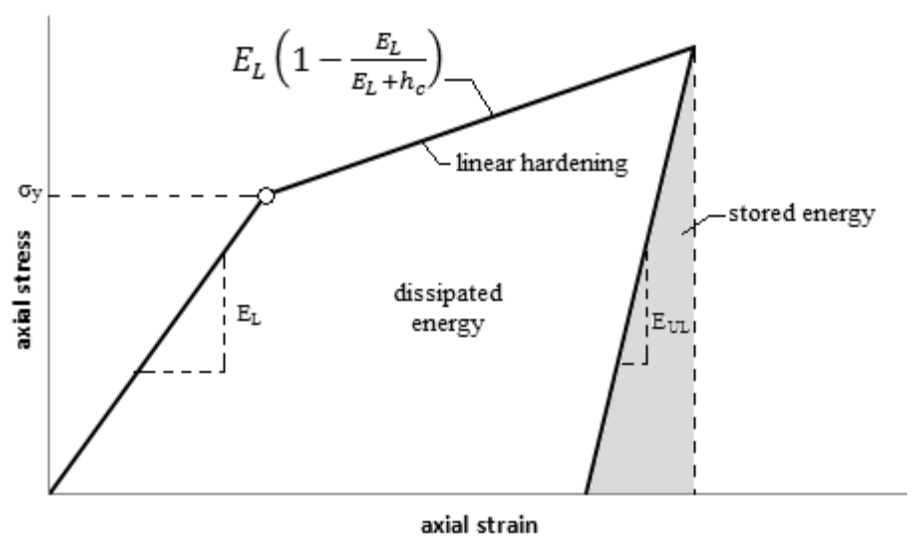

FIGURE 1. The Von Mises relationships during uniaxial test in stress-strain function 
desired (Wu et al. 2009, Wu and Chen 2010).

To find yield point on the basis of stress-strain function, $0.2 \%$ offset method is proposed. This method is used in metal tests with good results. Principles of this method are very simple. On plot of stress-strain relationship the elastic region is estimated by finding a straight line in the beginning of the test. Then, the same line with fixed slope equal to the Young modulus is printed in parallel to origin plot. Beginning of this line is in plus $0.2 \%$ on strain axis. The point of intersection of stress-strain function and $0.2 \%$ offset line is the point of yielding of material. Method of $0.2 \%$ offset is adopted to CBR test results only as a procedure of yield point estimation. Figure 2 presents $0.2 \%$ offset method. Therefore the CBR tests displacement will be calculated as strain in this case and axial strain in this paper should not be considered as axial strain from one-dimensional test.

Soil specimens were taken from a road construction site. Grade line of earthworks was on $0.7 \mathrm{~m}$, which means that the samples were subsoil material. For estimation of physical properties, series of tests were conducted. The sieve and aerometric the (Bouyoucos method, using a modification made by Casagrande) analysis lead to the classification of material as sandy-silty clay ( in accordance with standard PN-EN ISO 14688:2a (2006). Test results are shown in Figure 3. Studies have been performed under existing Polish standards PN-S-02205 (1998) and PN-88/B-04481 (1988).

Reymix product was used as stabilization medium which is dry mix of Portland cement, fractioned aggregates and chemical additives. Product was obtained as a common industrial package from ordinary building material store.

During the CBR tests samples were prepared in accordance with the existing Polish standards procedures. Compaction of specimens for CBR test was performed to obtain $0.59 \mathrm{~J} / \mathrm{cm}^{3}$ compaction energy with respect to optimum moisture content.

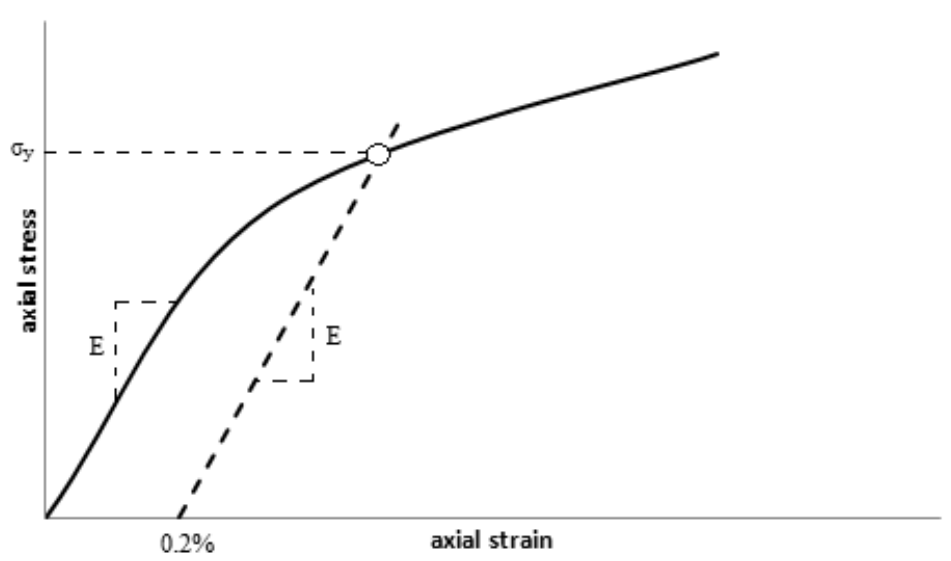

FIGURE 2. Principles $0.2 \%$ offset method 


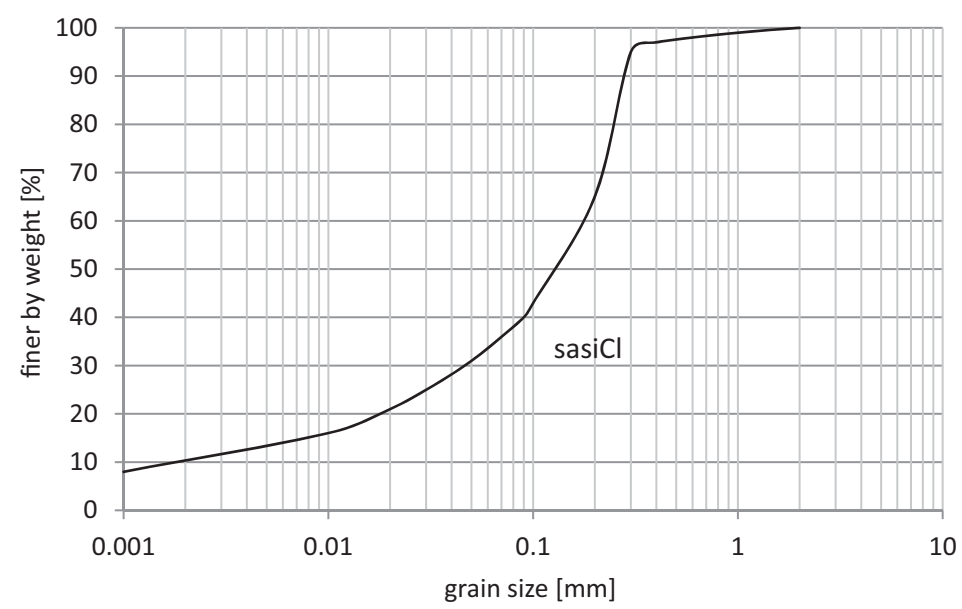

FIGURE 3. Particle size distribution in tested soil

Estimation of liquid limit was conducted in the Casagrande apparatus with the use of soil paste. On the basis of five tests performed on samples with different moisture content, plot of liquid limit was made (Fig. 4). Estimated liquid limit was $22.4 \%$. Such range of liquid limit classifies this soil as a clay with low plasticity.
Results of the Proctor test are presented in Figure 5. The test was conducted by the compaction in the Proctor mold, whose volume equaled $2.2 \mathrm{dm}^{3}$ with the use of standard energy of compaction, equaled $0.59 \mathrm{~J} / \mathrm{cm}^{3}$. Optimum moisture content for sandy-silty clay $\left(w_{\text {opt }}\right)$ was $8.7 \%$ and maximum dry density $\left(\rho_{d \max }\right)$ was $2 \mathrm{~g} / \mathrm{cm}^{3}$.

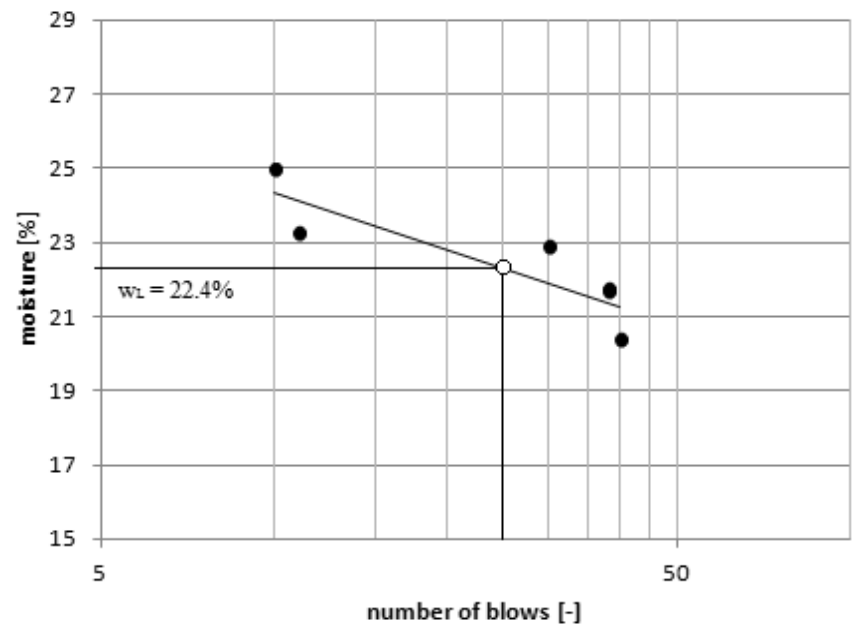

FIGURE 4. Liquid limit estimation test results 


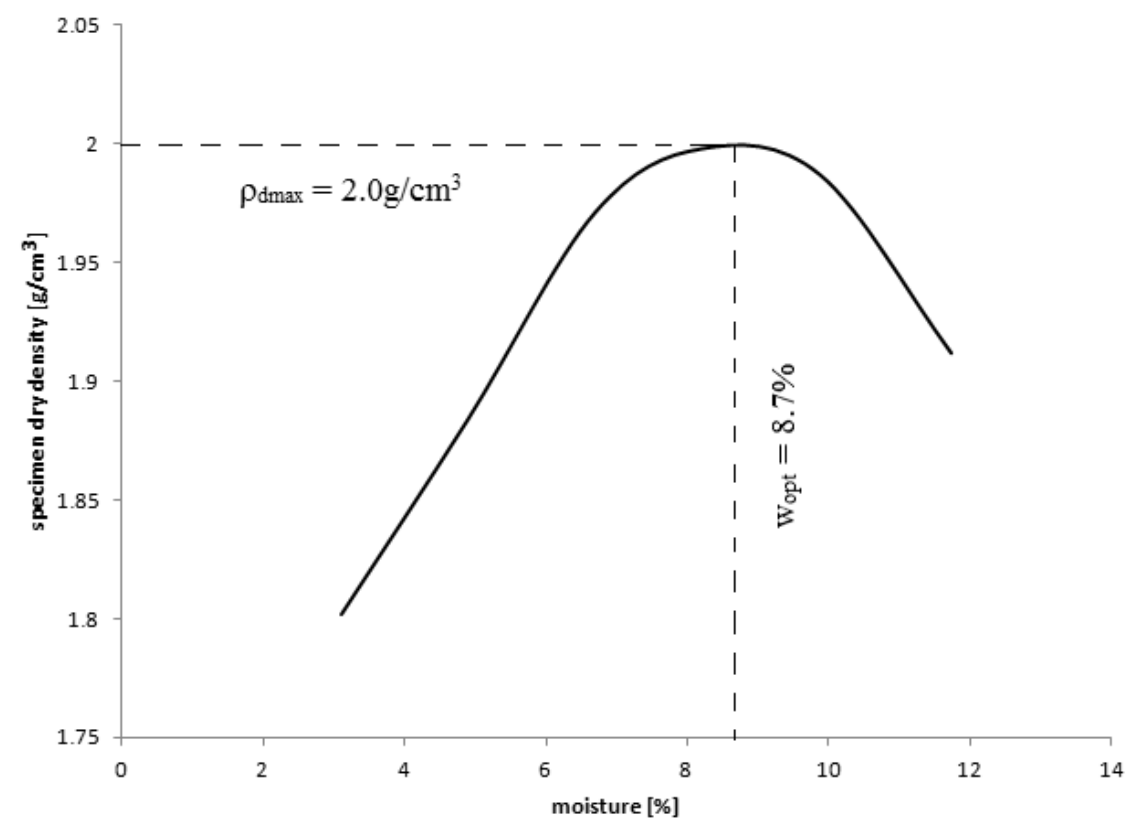

FIGURE 5. The Proctor test results for sandy-silty clay

\section{RESULTS}

The CBR tests were conducted until stress caused ultimate failure of bearing capacity in CBR test conditions. Results of these studies are presented in Figures 6 and 7. The first plot (Fig. 6) is a chart of CBR studies with $7 \%$ content stabilization medium with various levels of moisture. Second one (Fig. 7) presents CBR tests performed under constant moisture condition $(8.6 \%)$ and containing three different stabilization levels (5, 7 and $10 \%$ ).

Results of this test were then used for calculating the yield stress with respect to $0.2 \%$ offset method. Displacement expressed in millimeteres was converted to percentage value of strain. Initial height of CBR samples equals $1,800 \mathrm{~mm}$ for all specimens. The $0.2 \%$ strain therefore is equal $3.5 \mathrm{~mm}$ (exactly $0.195 \%$ ).
Figure 8 presents $3 \mathrm{D}$ view of $\mathrm{CBR}$ test results under constant moisture conditions at $8.6 \%$ after 7 and 28 days. The influence of Reymix addition on the increase of strength parameters can be clearly seen. Moreover, impact of time of stabilization is also clear. The graph surface analysis led to an equation being created, which contained these variables - equation (4).

$\ln z=a+b x^{0.5} \cdot \ln x+c x^{0.5}+d y^{-x}$

where:

$z$ - the axial stress $(\mathrm{MPa})$,

$y$ - Reymix content $(\%)$,

$x$-displacement $(\mathrm{mm})$,

$a$ to $d$ - constants: $a_{7}=-1.8020049$;

$\mathrm{b}_{7}=-0.84466548 ; \quad \mathrm{c}_{7}=3.166821589$;

$\mathrm{d}_{7}=-24.7271204$. 


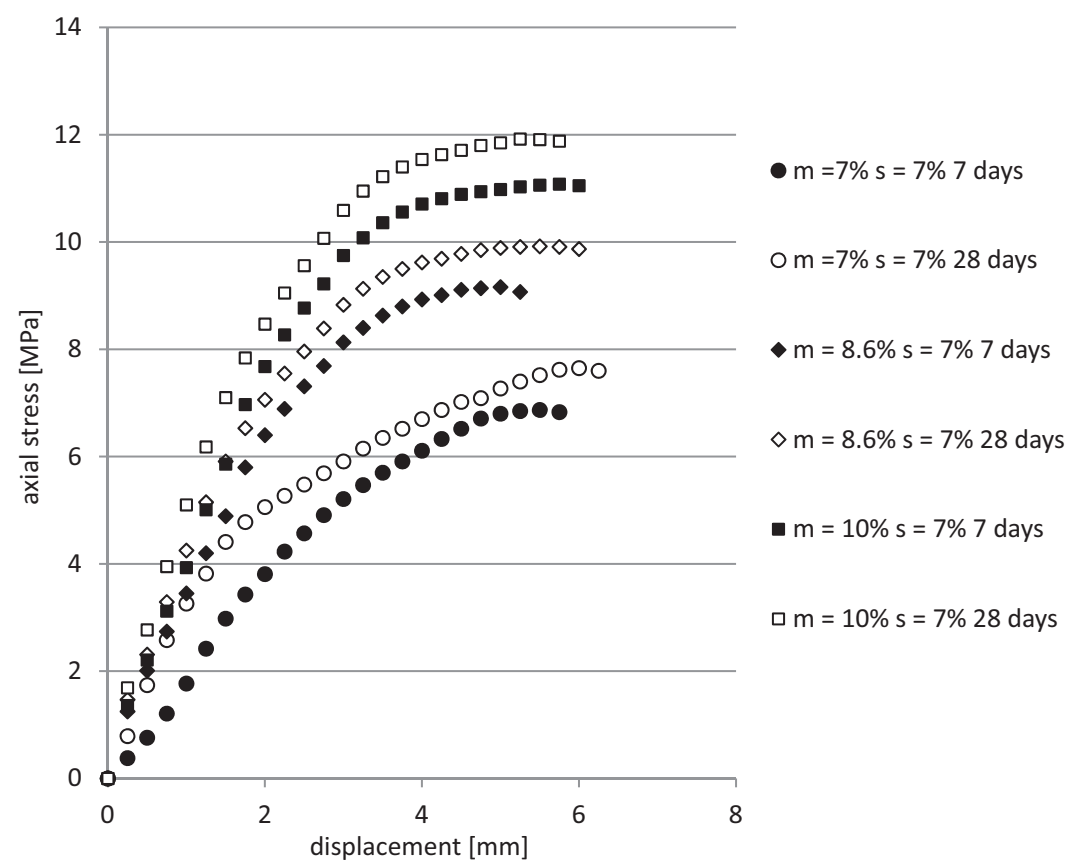

FIGURE 6. CBR test results for sandy-silty clay ( $\mathrm{m}$ - moisture, $\mathrm{s}-$ Reymix content constant)

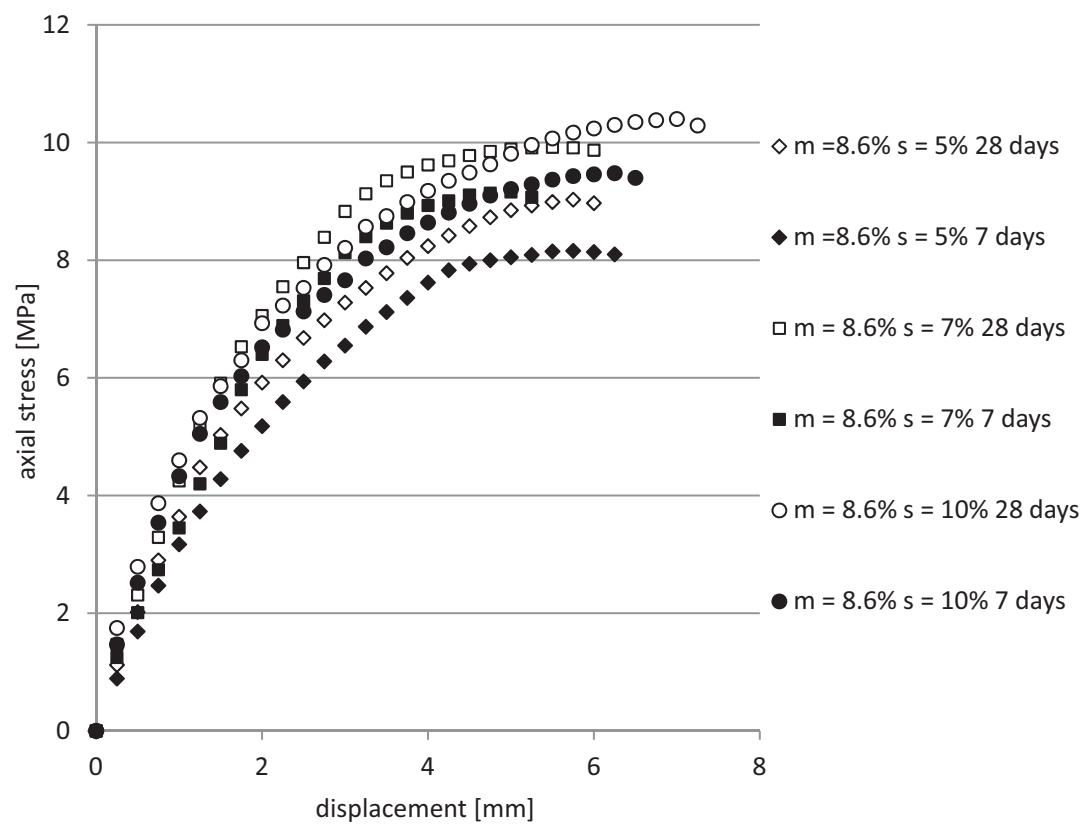

FIGURE 7. CBR test results for sandy-silty clay ( $\mathrm{m}-$ moisture constant, $\mathrm{s}-$ Reymix content) 


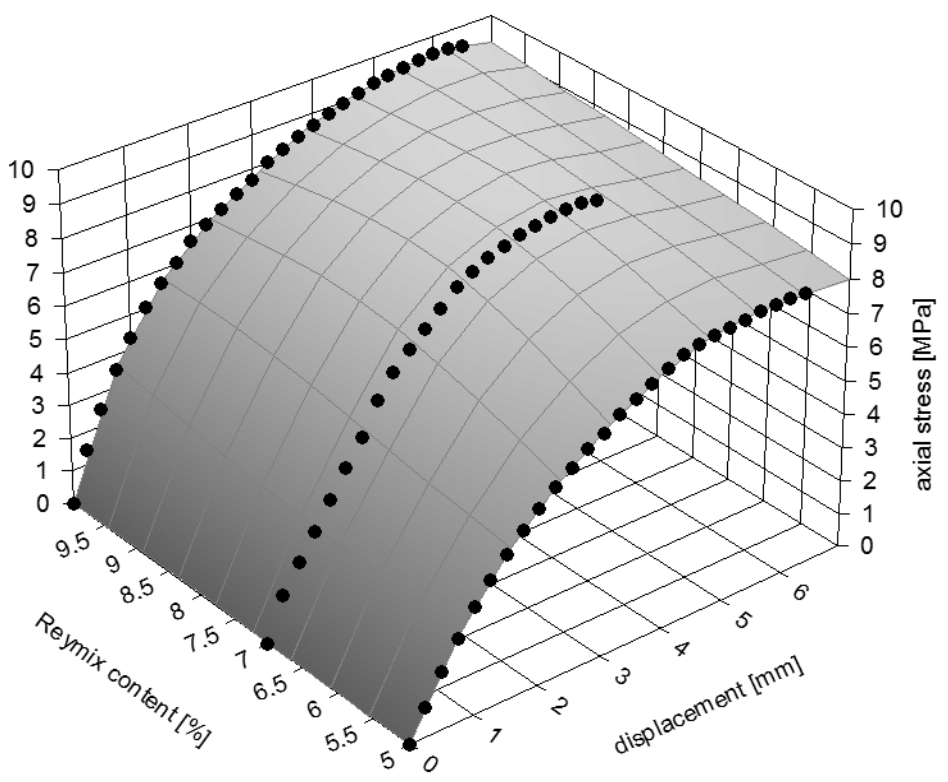

b

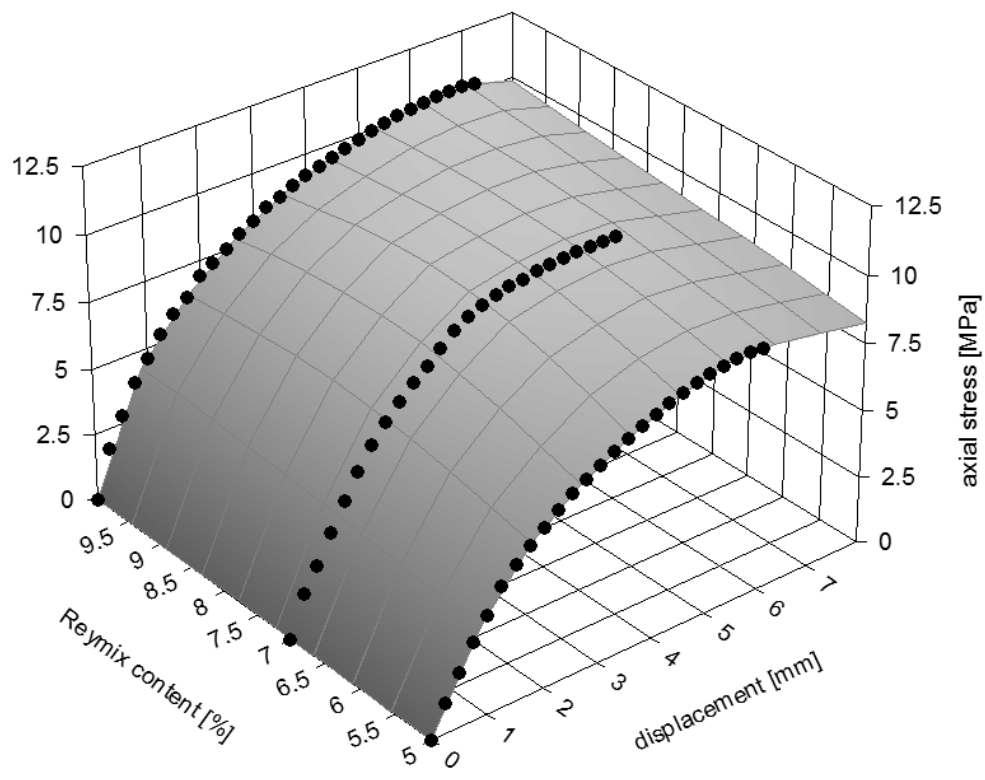

FIGURE 8. 3D view of CBR test results for various Reymix content in constant moisture conditions $(8.6 \%)$ after 7 days $-\mathrm{a}$, after 28 days $-\mathrm{b}$ 
An important fact is that equation (4) fits in case of both surfaces. The constants for $28^{\text {th }}$ day of stabilization are: $a_{28}=-1.35555496 ; b_{28}=-0.74592386$; $c_{28}=2.840314506 ; d_{28}=-21.0342633$ respectively. The $\mathrm{R}^{2}$ is 0.993 and 0.994 for both equations. The fact that these surfaces fit despite different times of stabilization can be understood as follows: the increase of strength parameters in time is proportional to the amount of stabilization medium content. That statement leads to the possibility of similarly improving the strength parameters curve for varying time factor, dependent only from stabilization medium content.

For purpose of $0.2 \%$ offset method application, Figure 9 presents input data used for next calculations. The method is presented on example of soil samples after 28 days from stabilization. All three samples were tested until bearing capacity of tested soil in CBR test conditions was obtained.
At the beginning of calculation, $0.2 \%$ offset criterion became too high. More reasonable data estimate the offset to be $0.05 \%$ and all calculations were enumerated in this manner. Figures 10, 11 and 12 present results of yield stress calculation and simplified function of loading in taken to consideration hardening rule. For specimens with 8.6 and $10 \%$ of moisture content the applied yield stress was close to bearing capacity failure point. Hardening function slope was low and failure took place in brittle manner.

This statement is comparable with actual observation during tests. Specimens with 5\% moisture content yield faster than two other samples and also hardening phenomena take longer to occur and the slope of hardening function is greater than in the case of different moisture contents. This occurrence could be caused by lower stabilization impact on soil structure due to insufficient

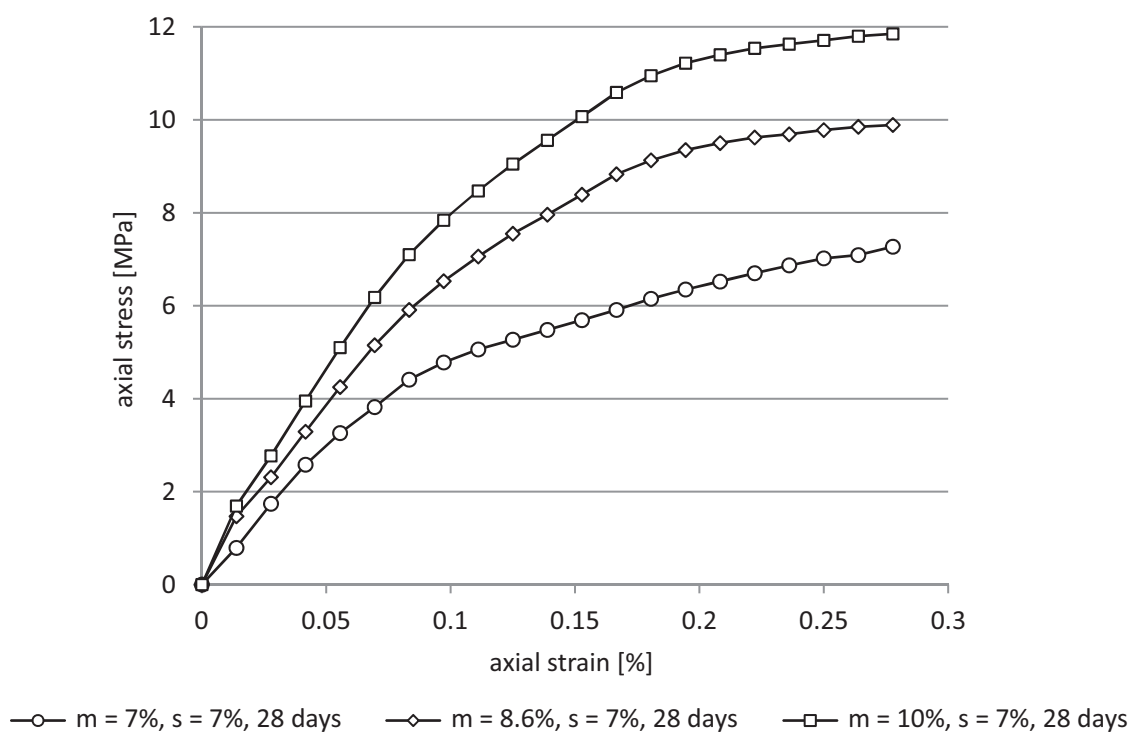

FIGURE 9. CBR test results in stress-strain function for calculation of yield stress 
148 Sas W., Gtuchowski A., Szymański A.

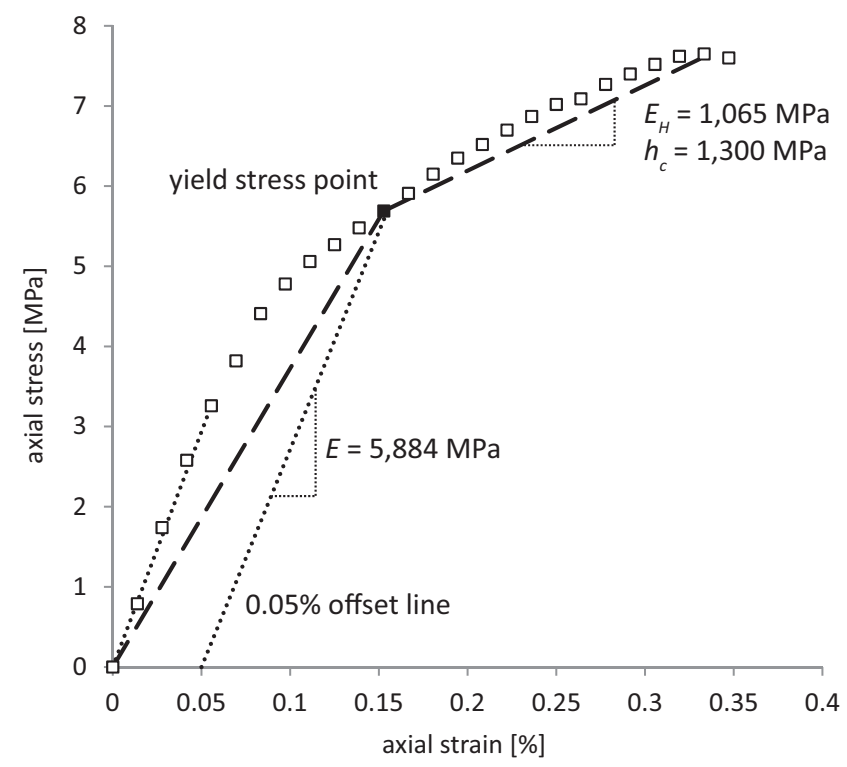

FIGURE 10. CBR test results and simplified interpretation in function of stress-strain for sandy-silty clay stabilized with $7 \%$ Reymix addition and $5 \%$ moisture content on the $28^{\text {th }}$ day of stabilization

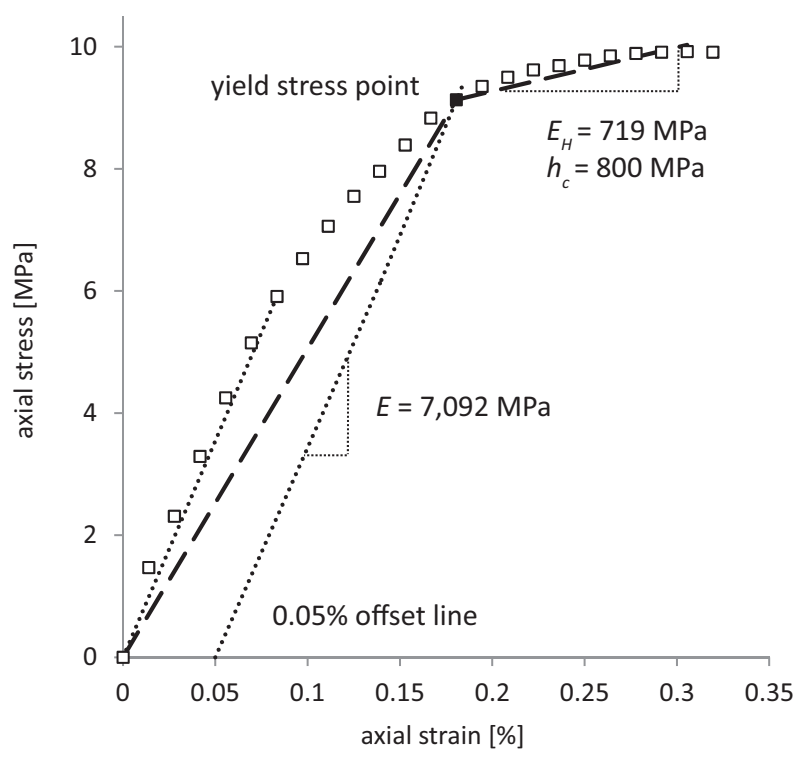

FIGURE 11. CBR test results and simplified interpretation in function of stress-strain for sandy-silty clay stabilized with $7 \%$ Reymix addition and $8.6 \%$ moisture content on the $28^{\text {th }}$ day of stabilization 


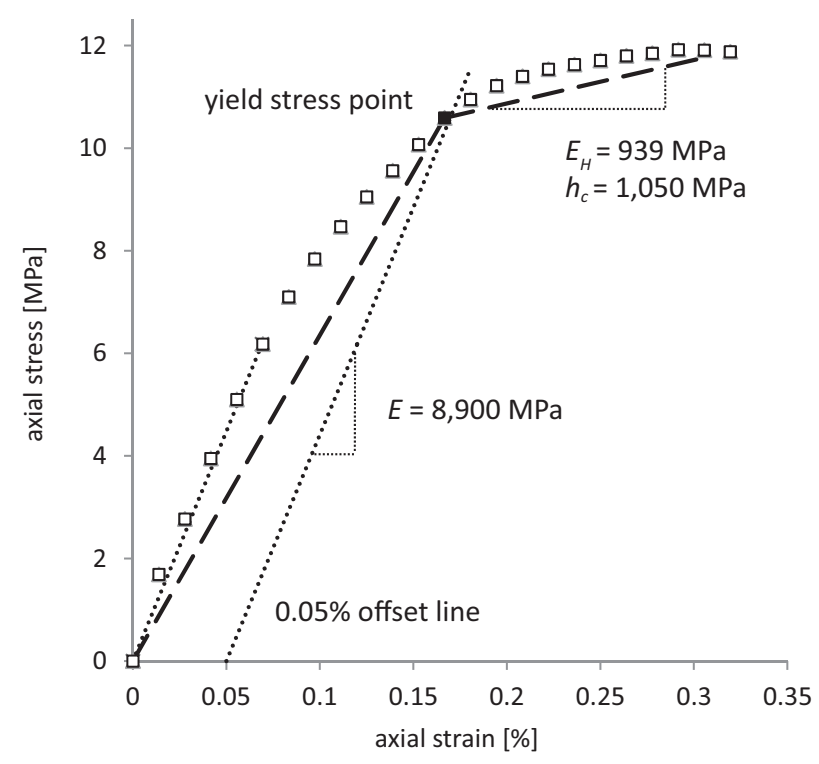

FIGURE 12. CBR test results and simplified interpretation in function of stress-strain for sandy-silty clay stabilized with $7 \%$ Reymix addition and $10 \%$ moisture content on the $28^{\text {th }}$ day of stabilization

water level in sample. Because of that, stress-strain behavior was softer, when compared brittle behavior of samples with larger moisture content.

The $5 \%$ moisture content sample has a hardening constant $\left(h_{c}\right)$ being equal to $1,300 \mathrm{MPa}$. The Young modulus $(E)$ of $0.05 \%$ offset line was $5,884 \mathrm{MPa}$. Slope of hardening linear function $\left(E_{H}\right)$ is equal $1,065 \mathrm{MPa}$; yield stress point $\left(\sigma_{y}\right)$ occurred at $5.69 \mathrm{MPa}$; ultimate bearing CBR capacity $\sigma_{T}=7.65 \mathrm{MPa}$. For $8.6 \%$ moisture content sample, $h_{c}=800 \mathrm{MPa}, E=7,092 \mathrm{MPa}, E_{H}=719$ $\mathrm{MPa}, \sigma_{y}=9.13 \mathrm{MPa}$ and $\sigma_{T}=9.92 \mathrm{MPa}$. Sample with $10 \%$ moisture content is characterized by the following values: $h_{c}=1,050 \mathrm{MPa}, E=8,900 \mathrm{MPa}, E_{H}=$ $=939 \mathrm{MPa}, \sigma_{y}=10.59 \mathrm{MPa}$ and $\sigma_{T}=$ $=11.92 \mathrm{MPa}$.

\section{CONCLUSIONS}

The research conducted in this paper and analysis of the yield phenomena of sandy-silty clay stabilized with Reymix lead to the following conclusions:

1. Analysis of the influence of Reymix stabilization medium on bearing capacity on the basis of the CBR tests lead to estimation of equation (4) which can be a useful tool for calculating CBR values in time of stabilization after the addition of Reymix.

2. Fitting surfaces for different time of stabilization are explained as the increase of the strength parameters in time is proportional for different stabilization medium content. It is also possible that similar improving strength parameters curve exists 
independently from the time factor and is only dependent on stabilization medium content.

3. For stabilized soil $0.02 \%$ offset method gives unsuitable results. Therefore $0.05 \%$ offset method was proposed as more appropriate.

4. The impact of moisture on hardening of yielding soil was noticed. Hardening phenomenon could be observed more clearly in samples with insufficient moisture content.

5. Proposed the von Mises criterion of hardening for stabilized brittle soils gives satisfactory results which can be applied for pavement engineering.

6. In common pavement design practice, CBR values are used for calculation of Young modulus or resilient modulus. Although this method assume linear physical law and due to polish code, higher value is taken for consideration while from CBR test bilinear physical law either can be obtain (Bak and Gosk 2007). Authors proposed $\sigma_{y}$ from CBR test as an important factor which can improve applicability of such empirical equations.

\section{REFERENCES}

BĄK G., GOSK W. 2007: Sztywność podłoża piaszczystego $\mathrm{w}$ procesach obciążenia $\mathrm{i}$ odciążenia wywołanych udarem. Czasopismo Techniczne Wydawnictwo Politechniki Krakowskiej 2: 3-10.

FAKHER A., JONES C.J.F.P., CLARKE B.G. 1990: Yield Stress of Super Soft Clays. Journal of Geotechnical and Geoenvironmental Engineering 125: 499-509.

LEMAIRE K., DENEELE D., BONNET S., LEGRET M. 2013: Effect of Lime and Cement Treatment on the Physicochemical, microstructural and mechanical characteristic of plastic silt. Engineering Geology 166: 255-261.
LEKHA B.M., RAVI SHANKAR A.U., SARANG G. 2013: Fatigue and Engineering Properties of Chemically Stabilized Soil for Pavements. Indian Geotechnical Journal 43(1): 96-104.

PN-88/B-04481, 1988: Grunty budowlane. Badania próbek gruntu. Polski Komitet Normalizacyjny, Warszawa [In Polish].

PN-EN ISO 14688:2a, 2006: Badania geotechniczne Oznaczanie i klasyfikowanie gruntów Część 2: Zasady klasyfikowania. Polski Komitet Normalizacyjny, Warszawa [In Polish].

PN-S-02205, 1998: Drogi samochodowe - Roboty ziemne - Wymagania i badania. Polski Komitet Normalizacyjny, Warszawa [In Polish].

PUZRIN A.M. 2012: Constitutive Modeling in Geomechanics. Springer, New York.

ROYALANCE D. 2001: Department of Material Science and Engineering, Report, Massachusetts Institute of Technology, Cambridge, October 24.

SAS W., GŁUCHOWSKI A. 2013: Effect Of Stabilization With Cement On Mechanical Properties Of Cohesive Soil - Sandy Clay. Annals of Warsaw University of Life Sciences. Land Reclamation 45(2): 193-0205.

SAS W., GŁUCHOWSKI A., MARGIELSKI J. 2013: Estimation Of Phisical And Mechanical Properties Of Cohesive Soil Stabilized By Hydratized Lime Addition. Annals of Warsaw University of Life Sciences. Land Reclamation 45(2): 143-157.

SKUTNIK Z., BAJDA M. 2008: Ocena jakości przesłony przeciwfiltracyjnej wykonanej w technologii DSM za pomocą sondowań geotechnicznych. Scientific Review. Engineering and Environmental Science 17, 4: 153-162 [Eng. Summary].

VIDAL C., INFANTE V. 2014: Fatigue Behaviour of Friction Stir-Welded Joints Repaired by Grinding. Journal of Materials Engineering and Performance 23(4): 1340-1349.

WU Z., CHEN X. 2010: Finite element sensitivity analysis of permanent deformation under accelerated loading. Proceedings of "GeoFlorida-Advances in Analysis, Modeling \& Design”, West Palm Beach, Florida, USA.

WU Z., CHEN X., ZHANG Z. 2009: A simplified numerical model proposed for simulation of permanent deformation of pavement base and subgrade materials. CD-ROM, Transportation 
Research Board of the National Academies, Washington, D.C., USA.

YANO K., WATARI Y., YAMANOUCHI T. 1985: Earthwork on soft clay grounds using rope netted fabrics. Proceedings of "Recent Developments in Ground Improvement Techniques": 225-237.

YU S.H. 2006: Plasticity and Geotechnics. Springer, New York.

ZABIELSKA-ADAMSKA K. 2008: Laboratory compaction of Ely Ash and Ely Ash with cement additions. Journal of Hazardous Materials $151,2-3$ : 481-489.

Streszczenie: Wplyw stabilizacji zageszczonego gruntu spoistego - itu piaszczystego na wzrost granicy sprężystości. Grunty słabe, które przejawiają niewielką wytrzymałość mechaniczną na obciążenia zewnętrzne, wymagają wzmocnienia. Stabilizacja chemiczna jest łatwa w wykonaniu i daje bardzo dobre wyniki wzrostu właściwości mechanicznych. W artykule przedstawiono wyniki badania CBR oraz jednoosiowego ściskania gruntu spoistego - iłu piaszczystego ulepszonego za pomoca preparatu Reymix, który jest pochodną cementu. Przeprowadzone badania miały na celu określenie charakterystyki poprawy właściwości mechanicznych oraz wyznaczenie dla stabilizowanego gruntu granicy sprężystości, która jest inna niż w przypadku gruntów niestabilizowanych.

Stowa kluczowe: stabilizacja, Reymix, granica sprężystości, grunty spoiste, jednoosiowe ściskanie, CBR

MS. received in May 2014
Authors' address:
Wojciech Sas
Laboratorium Centrum Wodne
ul. Ciszewskiego 6
02-776 Warszawa, Poland
e-mail: wojciech_sas@sggw.pl 